Huchzermeyer, C. F. et al. (2017). First record of epizootic ulcerative syndrome from the Upper Congo catchment: an outbreak in the Bangweulu swamps, Zambia.

\title{
First record of epizootic ulcerative syndrome from the Upper Congo catchment: An outbreak in the Bangweulu swamps, Zambia
}

C. F. Huchzermeyer, K. D. A. Huchzermeyer, K. W. Christison, B. M. Macey, P. A. Colly, B. M. Hang'ombe and M. M. Songe

\begin{abstract}
We report on the first outbreak of epizootic ulcerative syndrome (EUS) amongst wild fish populations in the Bangweulu swamps, an inland delta, in the north of Zambia during 2014. The area supports a large and diverse fish fauna related to, but distinct from, that of the Zambezi River system where EUS outbreaks have occurred since 2006. A sizeable artisanal fishery, based on extensive fish weirs, is sustained by the annual flooding of the swamps, and observations of the disease outbreak by fishermen were recorded. Signs typical of infection with Aphanomyces invadans were observed in a number of species. Clinical observations, histology and molecular diagnostic methods were used to confirm infection with A. invadans in two of the most commonly and severely affected species. Several features of the wetland may have contributed to the outbreak and the annual recurrence of the disease. Modes by which the disease may have been introduced into the swamps are discussed. The outbreak is of great significance as the Bangweulu swamps drain into the Congo River in neighbouring Democratic Republic of Congo, Africa's largest drainage system with an extensive and diverse fish fauna previously unaffected by EUS.
\end{abstract}

\section{Introduction}

Epizootic ulcerative syndrome (EUS) is a serious disease of freshwater and estuarine fish. The disease has been reported from Asia, Australia, North America and Africa (Anon 2016a; Oidtmann, 2012). The first reports from Africa followed an outbreak in the Zambezi and Chobe rivers near their confluence in 2006 (Andrew, Huchzermeyer, Mbeha, \& Nengu, 2008; Anon 2009a). It remains unknown how the causative agent, Aphanomyces invadans, spread to Africa. The disease appears to have originated in Asia, with the first reporting of a new ulcerative disease of fish from Japan in 1971 (Egusa \& Masuda, 1971). A year later, the disease was reported from Australia (Baldock et al., 2005; Callinan, Paclibare, Bondad-Reantaso, Chin, \& Gogolewski, 1995), and since then has been described from many countries, particularly in Asia (Callinan et al., 1995; Das \& Das, 1993; Lilly et al., 1997), but also from natural populations of estuarine and freshwater fish along the Atlantic coast of the USA (Blazer et al., 2002; Sosa et al., 2007). The spread of $A$. invadans to distinctly separate geographic regions within a relatively short period of time has been consistent with the progressive dissemination of a 
single infectious agent (Baldock et al., 2005; Lilly et al., 1997) and illustrates the potential rapidity with which aquatic pathogens can spread. There are many countries from which the disease has not been reported including those of the South American and European continents (Anon 2016a; Oidtmann, 2012). Consequently, EUS is listed as notifiable to the World Organization for Animal Health (OIE) by its member countries and raises biosecurity concerns for the translocation of fish both nationally and internationally.

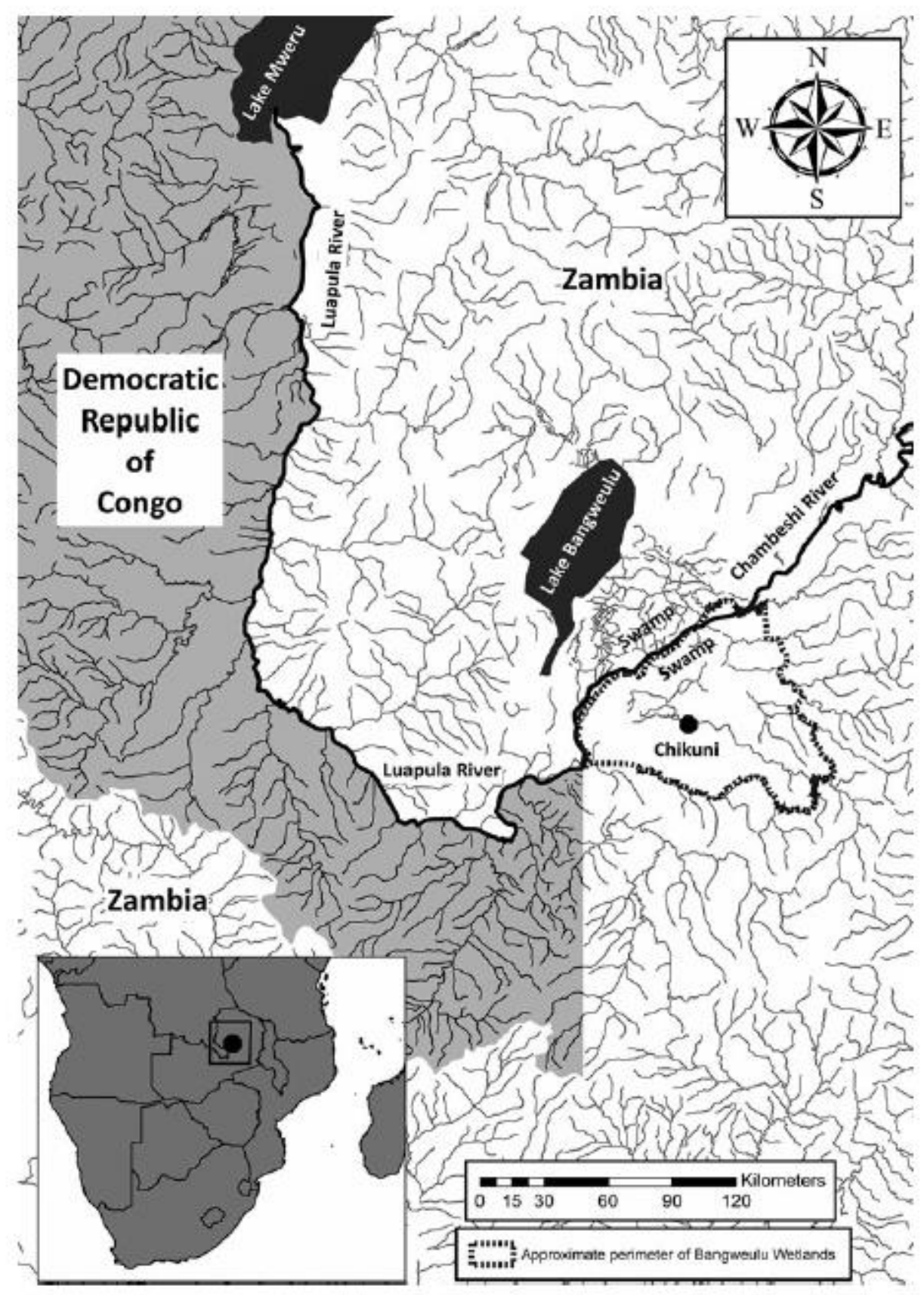

FIGURE 1 Map showing the position of Chikuni Station,

Bangweulu Wetlands and the surrounding river drainages of the Bangweulu-Mweru Freshwater Ecoregion which stretches from the source of the Chambeshi River to the outflow of Lake Mweru 
The confluence of the Zambezi and Chobe rivers represents an area of rich species diversity. A. invadans shows little host specificity, and by 2008, the disease had been observed in 22 different indigenous species of fish in this area alone (Huchzermeyer \& Van der Waal, 2012; Songe et al., 2012), and from over 93 species of fish to date, many of these from the Zambezi floodplains in Southern Africa (Anon 2016a). The disease has subsequently been reported in 2010 from the Okavango Delta in Botswana (Anon 2011), an inland delta where the Kavango River drains into the Kalahari Desert, and in 2011, from Lake Liambezi in Namibia (McHugh, Christison, Weyl, \& Smit, 2014). Lake Liambezi receives inflow from the Zambezi, Chobe and Linyati rivers and, as in the case of the Zambezi floodplains, supports a thriving artisanal fishery. By 2014, outbreaks of the disease in South Africa were reported from divergent catchments with no connection to the Zambezi: the Palmiet and Eerste rivers in the Western Cape Province (Huchzermeyer \& Van der Waal, 2012) and the Limpopo catchment in the Northwest Province (K. D. A. Huchzermeyer, unpublished observation 2014).

Within the Zambezi catchment, the floodplain ecosystems of the upper Zambezi in Zambia, Angola, Namibia, Botswana and Zimbabwe and of the Kafue River in Zambia have been impacted by EUS. The disease has shown its most rapid spread in Zambia, a land-locked country of high summer rainfall and a species-rich fish fauna.

In this article, we report on the first confirmed outbreak of EUS in Bangweulu Wetlands, a public-private conservation partnership that manages the Game Management Areas (GMAs) of the south-eastern part of the Bangweulu swamps in northern Zambia, encompassing an area of 4,000 km² (Anon 2016b) (Figure 1), and provide the first documentation of spread of the disease into the Upper Congo River catchment. We describe EUS from a number of species.

\section{Materials and methods}

\subsection{Sampling andobservations}

The occurrence of a potentially notifiable disease of fish in the Lukulu Delta, around Chikuni Station, in Bangweulu Wetlands was reported to the relevant authorities on 6th May 2014. Fishery monitors in the employ of Bangweulu Wetlands, who interact with local fishermen, were alerted, and observations of fish with signs indicative of EUS were recorded. Local fishermen were interviewed, and their beliefs as to possible causes of the observed signs were recorded. To confirm the disease, tissue samples were collected from six Enteromius paludinosus Peters and from six Clarias gariepinus (Burchell) specimens, with signs typical of EUS, caught in the channels of the river from the 27th to 30th May 2014. All sampled sick fish were killed with an overdose of clove oil. Tissue specimens from C. gariepinus comprising skin, dermis and muscle were collected from the edge of ulcers extending across the margin of the ulcer to include adjacent healthy/normal appearing tissue. From each fish, one tissue sample measuring approximately $109595 \mathrm{~mm}$ was fixed in 10\% buffered formalin for histological processing and a sample of approximately half this size was fixed in $98 \%$ ethanol for analysis by polymerase chain reaction (PCR) for the presence of $A$. invadans genomic DNA. Cross sections of the entire body, 5-10 $\mathrm{mm}$ in thickness, and incorporating the observed lesions, were collected from the much smaller E. paludinosus and were fixed in the same manner.

\subsection{Histology}

The formalin fixed tissue was processed by standard histological technique, and 5-lm sections were stained with haematoxylin and eosin (H\&E) and with Grocott's methenamine silver

\section{https://repository.uwc.ac.za/}


(GMS) stain. The sections were examined by standard light microscopy for presence of histological changes pathognomonic of EUS.

\subsection{Molecular diagnosis}

Tissue samples collected from C. gariepinus ( $n=4$ specimens) and E. paludinosus $(n=1$ specimen) were processed for PCR to confirm whether the samples were infected with $A$. invadans. Ethanol-fixed tissue samples for PCR were placed in $300 \mathrm{ll}$ STE buffer (100 $\mathrm{mmol} / \mathrm{L} \mathrm{NaCl}, 50 \mathrm{mmol} / \mathrm{L}$ Tris-HCl, $1.26 \mathrm{mmol} / \mathrm{L}$ EDTA, $\mathrm{pH}$ 7.5), supplemented with $2 \%$ $(\mathrm{w} / \mathrm{v})$ sodium dodecyl sulphate (SDS) and proteinase $\mathrm{K}(0.3 \mathrm{mg} / \mathrm{ml})$ and incubated at $56^{\circ} \mathrm{C}$ overnight. Genomic DNA was extracted using standard phenol-chloroform and ethanol precipitation methods (Sambrook, MacCallum, \& Russel, 2000). The resultant supernatants containing isolated genomic DNA were stored at $-20^{\circ} \mathrm{C}$ untilneeded.

A 550-bp fragment of the $A$. invadans internal transcribed spacer (ITS) gene was amplified using EUS-specific primers recommended by the OIE (Anon 2016a), namely forward primer ITS-11 (5 $5_{-}^{\mathrm{O} C C}$ GAA GTT TCG CAA GAA AC-3 $3^{\mathrm{O}}$ ) and reverse primer ITS-23 (5 ${ }^{\mathrm{O}}$ CGTG ATA GAC ACA AGC ACA CCA- $3^{\mathrm{O}}$ ) of Phadee, Kurata, and Hatai (2004). The reaction mixtures (25 ll) were prepared using 50 ng genomic DNA, 29 KAPA Taq Ready Mix (KAPA Biosystems, Cape Town, South Africa) and $400 \mathrm{nmol} / \mathrm{L}$ forward primer and $400 \mathrm{nmol} / \mathrm{L}$ reverse primer. Amplification was conducted using the Labnet Multigene Thermal Cycler (Labnet International, Inc.) and consisted of an initial denaturation of $5 \mathrm{~min}$ at $94^{\circ} \mathrm{C}$, followed by 25 cycles of $30 \mathrm{~s}$ at $94^{\circ} \mathrm{C}, 30 \mathrm{~s}$ at $56^{\circ} \mathrm{C}$ and $1 \mathrm{~min}$ at $72^{\circ} \mathrm{C}$, with a final extension of $5 \mathrm{~min}$ at $72^{\circ} \mathrm{C}$. Known amounts of $A$. invadans DNA served as a positive control. In addition, nontemplate controls (PCR-grade $\mathrm{H}_{2} \mathrm{O}$ ) were analysed to ensure that the reagents were not contaminated and there was no amplification except for the $A$. invadans DNA. The amplified PCR products ( $5 \mathrm{ll}$ ) were analysed by $0.8 \%$ agarose gel electrophoresis to verify reaction specificity and fragment size before being purified using a PCR purification kit (Roche) according to the manufacturer instructions. The purified ITS rRNA PCR products were sequenced using a BigDye Terminator Cycle Sequencing Kit (Applied Biosystems) and ABI3730xl Genetic Analyzer (Applied Biosystems) according to the sequencer manufacturer's instructions. Both forward and reverse primers (ITS-11 and ITS-23, respectively) were used for cycle sequencing. Sequences were edited and assembled using CLC Main Workbench version 6.9 (CLC Bio, www.clcbio.com). Homology searches were carried out using the BLASTN algorithm (Altschul, Gish, Miller, Myers, \& Lipman, 1990) provided by the Internet service of the National Centre for Biotechnology Information (http://www.ncbi.blast.nlm.nih.gov/ BLAST/).

\section{Results}

\subsection{Observations of disease}

Visibly sick and weak fish with focal red and ulcerative lesions were initially detected on 30 th April 2014 along a drying channel at Chikuni Station ( $11^{\circ} 58^{\circ} 05^{\prime \prime} S ; 30^{\circ} 15^{\mathrm{O}_{1}}$ " E), where the Lukulu River forms a delta entering the Bangweulu swamps (Chiundaponde Chiefdom, Mpika District, Zambia). The first sick fish noticed were thought to have been injured by birds or by trap baskets used by fishermen. On the evening of 1st May 2014, a large number $(n>50)$ of juvenile catfish (Clarias spp., 150-180 mm in length) were seen in shallow water, all exhibiting pink, round skin lesions. In the following days, moribund fish with the aforementioned skin

\section{https://repository.uwc.ac.za/}


lesions were observed dying. In addition to Clarias spp., similar red skin lesions were noticed in two other species: E. paludinosus and E. trimaculatus Peters. Fish with lesions were weak or immobile, with a retarded ability to flee capture. Most observations were made in shallow water, away from currents. Sick fish were rarely encountered in deeper water. Various water birds were noticed preying on sick fish and removing dead fish.

On 3 rd of May, fish with lesions were reported from two fishing camps, $1 \mathrm{~km}$ and $3 \mathrm{~km}$ from Chikuni, along the edge of the same floodplain. Here, several adult Clarias spp. (400-450 $\mathrm{mm}$ in length) were observed with lesions, and fishermen reported seeing lesions on many of the smaller Enteromius spp. On the 5th May, Clarias spp. with lesions were observed elsewhere within a $3 \mathrm{~km}$ radius of Chikuni. In the following weeks, reports were received that the disease was being seen in various areas up to $15^{-20} \mathrm{~km}$ away from the site of initial observation.

Fishermen confirmed that they had never before seen a disease like this in the area. A range of explanations were developed ranging from bird injuries, to witchcraft and deliberate infection of the fish as a punitive measure by authorities. Fishing communities were concerned about the safety of consuming and trading infected fish, while the rapid emergence and spread of the disease lead others to fear extinction of the fish stocks. The emergence of the disease was becoming a major issue in the fishing communities and beginning to result in unrest.

\subsection{Suspicion of EUS}

The size, shape and occurrence of skin lesions on multiple fish species, ranging from focal areas of intense inflammation and hyperaemia of the skin to deep ulcerations with exposure of underlying muscle (Figure 2a-e), were consistent with the field signs of EUS listed in an FAO extension booklet (Anon 2009b) and reported elsewhere in theliterature (Anon 2016a).

Species recorded with EUS-like lesions were C. gariepinus (very commonly with lesions) (Figure 2a, b and e), C. ngamensis Castelnau (lesions fairly common), C. theodorae Weber (rarely with lesions), E. paludinosus (very commonly with lesions) (Figure 2c), Ctenopoma multispine Peters (common, often with secondary oomycete infections and raised scales) (Figure 2d), E. trimaculatus (commonly with lesions), while Marcusenius macrolepidotus (Peters) and Pollimyrus isidori (Valenciennes) only occasionally exhibited small lesions on the caudal peduncle and fin. Two very abundant cichlid fishes, Pseudocrenilabrus philander (Weber) and Tilapia sparmanni A. Smith, were not observed to be affected. The presentation of lesions differed to some extent amongst the species observed (Figure 2). In the scaleless Clarias spp., lesions were usually well-defined open ulcers (Figure 2a and e). In Enteromius spp., lesions often remained covered with scales and were usually confined to the trunk or fin bases. Ctenopoma presented with unusual, diffuse lesions across the entire body with less visible inflammation. 

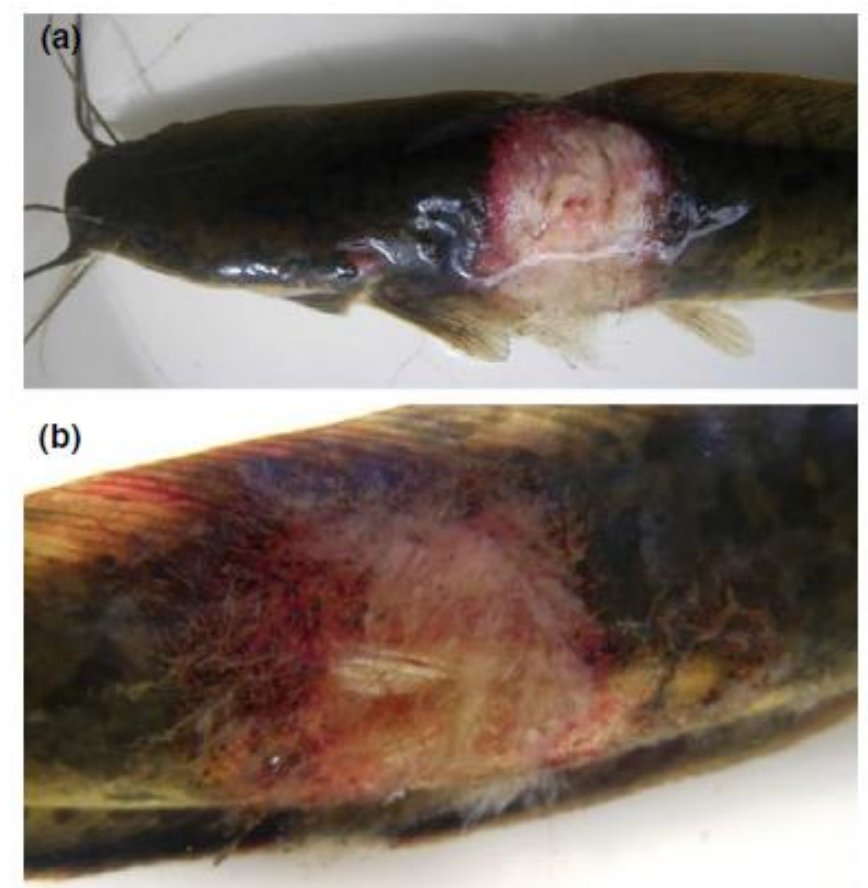

(c)
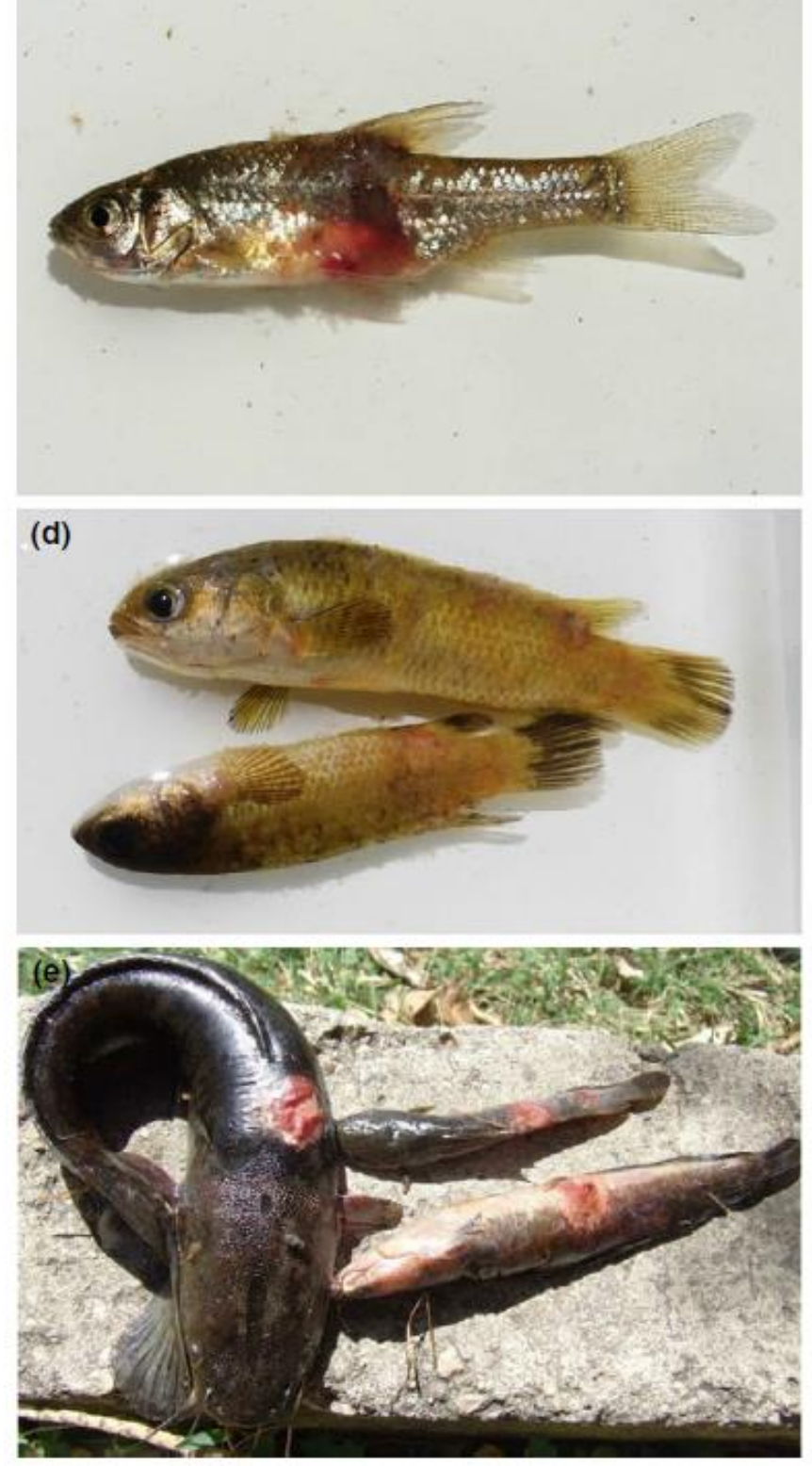

https://repository.uwc.ac.za/ 


\subsection{Histopathology}

Examination of histological sections of lesions in skin and muscle stained with $\mathrm{H} \& \mathrm{E}$ revealed oomycete hyphae and associated granulomatous tracts penetrating deeply into necrotic muscle tissue in the samples collected from the $E$. paludinosus and $C$. gariepinus specimens (Table 1). Within the granulomatous tracts, branching oomycete hyphae were visible surrounded by a dense sheath of inflammatory cells consisting predominantly of macrophages and fibroblasts with occasional giant cells (Figure 3a). Sections stained with GMS highlighted the depth to which hyphae invaded the tissues (Figure $3 b$ ). In sections from a single specimen of $E$. paludinosus that presented with an ulceration on the head, oomycete hyphae were observed within several areas of the brain (Figure 3c). Smaller diameter non-invasive hyphae, typical of opportunistic saprophytic oomycetes, were frequently observed covering the surface of the ulcerative lesions.

\subsection{Molecular diagnosis}

Genomic DNA isolated from E. paludinosus (sample BW-A1) and C. gariepinus (samples BW-A2, BW-A3, BW-A4 and BW-A5) was subjected to PCR. The genomic DNA included as positive controls, as well as all of the tissue samples that were tested, produced a positive result in the PCR, yielding a band of expected molecular weight ( 550 -bp for the ITS gene) (Phadee et al., 2004). No amplification occurred in the nontemplate control sample, confirming the specificity of the PCR reactions.

To further validate the presence of $A$. invadans in the aforementioned samples, the ITS gene sequence of each PCR product was determined. Nucleotide sequences greater than $500 \mathrm{bp}$ in length were determined for all samples, with the exception of sample BW-A2. Poor or "dirty" sequence data was obtained for the later sample, and as a consequence, the data were omitted from further analysis. The remaining nucleotide sequence data were deposited in GenBank database as accession numbers KU529683, KU529684, KU529685 and KU529686 for samples BW-A1, BW-A3, BW-A4 and BW-A5, respectively. Analysis of the nucleotide sequences showed 100\% concordance amongst the samples. Furthermore, a BLAST search of the GenBank database revealed that the gene sequence of each PCR product had $100 \%$ similarity to all the A. invadans ITS gene sequences that have previously been deposited in the GenBank database, supporting the PCR findings in this study and confirming the presence of the causative agent of EUS in the tested samples. 
TABLE 1 Results of macroscopic, histological and molecular examinations of fish tissues collected during the 2014 outbreak of epizootic ulcerative syndrome (EUS) in Bangweulu Wetlands in the upper catchment of the Congo River in the north of Zambia

\begin{tabular}{|c|c|c|c|c|c|}
\hline Species & $\begin{array}{l}\text { Individuals collected with } \\
\text { macroscopic lesions } \\
\text { typical of EUS ( } n \text { ) }\end{array}$ & $\begin{array}{l}\text { Individuals examined } \\
\text { by histology }(n)\end{array}$ & $\begin{array}{l}\text { Granulomatous myonecrosis } \\
\text { with invading oomycete } \\
\text { hyphae in histological } \\
\text { specimens ( } n \text { ) }\end{array}$ & $\begin{array}{l}\text { Individuals } \\
\text { examined by } \\
\text { PCR (n) }\end{array}$ & $\begin{array}{l}\text { Identification of genomic } \\
\text { DNA of Aphanomyces } \\
\text { invadans }(\boldsymbol{n})\end{array}$ \\
\hline Enteromius paludinosus & 6 & 4 & 4 & 1 & 1 \\
\hline Clarias gariepinus & 6 & 6 & 6 & 4 & 3 \\
\hline
\end{tabular}
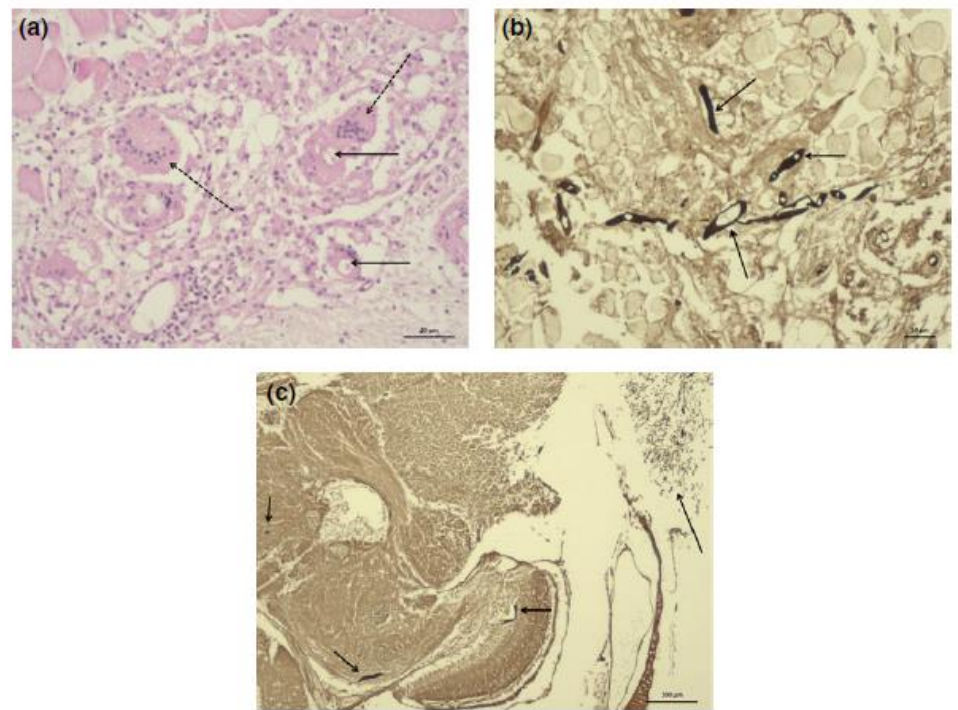

FIGURE 3 Histological appearance of lesions associated with infection by Aphanomyces invadans in two of the most commonly affected species during the outbreak of epizootic ulcerative syndrome (EUS) in Bangweulu Wetlands, Northern Zambia, during 2014. (a) Granulomatous tract surrounding invading oomycete hyphae (plain arrows) within an area of necrotic muscle tissue in a Clarias gariepinus specimen. Note the Langhans giant cells (stippled arrows) associated with the granulomatous tracts. $H \& E \times 400$. (b) Section through muscle from below the margin of an ulcerated area of skin of a C. gariepinus specimen. Note the actively invading black-staining hyphae (arrow) of A. invadans. Grocott's methenamine silver stain. $\times 400$. (c) Cross section of the head of a Enteromius paludinosus specimen affected by EUS with ulceration on the dorsum of the head. Note the A. invadans hyphae that have penetrated deeply into parts of the brain (short arrows). The long arrow marks the position of the ulcer covered by hyphae of an opportunistic non-pathogenic water mould. Grocott's methenamine silver stain. $\times 40$

\section{Discussion}

This study confirms the first cases of EUS from the Bangweulu swamps. The presence of a granulomatous myonecrosis associated with deeply invading branched oomycete hyphae, observed histologically in tissues from the sampled fish, was consistent with infection by $A$. invadans and served as one of the confirmatory tests required for a diagnosis of EUS (Anon 2016a). In addition, the samples from C. gariepinus and E. paludinosus that tested positive by molecular means satisfied the conditions required for PCR analyses for confirmed cases of EUS as it is currently regarded by the OIE (Anon 2016a). Isolates of $A$. invadans from around the world have been shown to be homologous (Anon 2016a; Baldock et al., 2005; Lilly et al., 1997). Consistent with these previous findings, we observed a complete lack of genetic diversity between the $A$. invadans isolates obtained from $C$. gariepinus and $E$. paludinosus as well as $100 \%$ homology with all $A$. invadans ITS sequences deposited in the Gen-Bank database.

The Zambian Department of Fisheries (Ministry of Livestock and Fisheries) were formally notified of the disease outbreak, and a far-reaching education campaign was begun by Bangweulu Wetlands through its community extension officers and the fisheries comanagement committee active in the area. This contributed to quelling the unrest amongst the fishing community by addressing the fishermen's fears of loss of livelihood. 
The Chambeshi/Luapula River, regarded as the source of the Congo River (Scott, 2005), and the extensive, oligotrophic Bangweulu swamps with their large, seasonal floodplains, covers a basin of $15,000 \mathrm{~km}^{2}$ before draining into the Congo River in the Democratic Republic of Congo (DRC) (Kolding, Ticheler, \& Chanda, 2003). The Bangweulu swamps form part of the Bangweulu-Mweru Freshwater Ecoregion and contain a significant richness of aquatic biodiversity and a fish fauna that, although related to that of the Zambezi system, shows a greater similarity to the ichthyofauna of the Congo Basin (Scott, 2005; Van Steenberge, Vreven, \& Snoeks, 2014). The region is considered globally outstanding and of highest conservation priority (Scott, 2005). The Congo Basin has an ichthyofaunal endemism of 75\% (Van Steenberge et al., 2014), which now stands to be impacted by EUS. Subsequent to this study, the first outbreak of EUS in the Congo Basin was reported from the DRC in 2015, affecting the Equateur Province in the north-west of that country (Anon 2017).

The Bangweulu floodplain and swamp supports one of the largest artisanal fisheries in Zambia (Musumali, Heck, Husken, \& Wishart, 2009). Fish are harvested seasonally through an extensive and unique network of fish weirs that cover some $7,000 \mathrm{~km}^{2}$ (Huchzermeyer, 2013; Kolding et al., 2003; McKey et al., 2016). This provides the main source of livelihood for an estimated 5,000 fishing families within Bangweulu Wetlands, generating income of approximately $\$ 6$ million annually (C. F. Huchzermeyer, unpublished report 2013). Therefore, sustainable management of the fishery forms a central part of the conservation strategy of Bangweulu Wetlands (Anon 2016b).

Freshwater and estuarine ecosystems in tropical and subtropical climates are particularly vulnerable to outbreaks of EUS (Boys et al., 2012). Initial outbreaks of disease in Africa (Andrew et al., 2008; Anon 2009a; Huchzermeyer \& Van der Waal, 2012; McHugh et al., 2014; Songe et al., 2012) have been particularly severe in floodplain ecosystems as observed during this study in the Bangweulu swamps where the initial severe outbreak of 2014 was followed by annual reappearance of the disease during the same months in 2015, 2016 and 2017 (personal observations C. F. Huchzermeyer, Bangweulu Wetlands, Chikuni, Zambia 2017). Following the initially severe epidemic, the seasonal resurgence of the disease observed in this study was similar to that reported during outbreaks of EUS in the upper Zambezi (Huchzermeyer \& Van der Waal, 2012; Nsonga, Mfitilodze, Samui \& Sikawa, 2013) and in other parts of the world (Boys et al., 2012; Pradhan et al., 2014). As with the initial outbreaks of EUS in the Zambezi floodplains, reported by Huchzermeyer and Van der Waal (2012), fishermen in the Bangweulu swamps soon accepted the presence of the disease. Understanding the potential impact that the seasonal resurgence of epidemic outbreaks may have on the long-term species composition and economic patterns of the fishery will be important but was beyond the scope of this study.

The species most frequently affected by EUS during this out break, C. gariepinus, C. ngamensis and E. paludinosus, have previously been identified as highly susceptible to EUS during outbreaks in the Zambezi floodplains (Huchzermeyer \& Van der Waal, 2012; Songe et al., 2012). C. theodorae manifested lesions only rarely during the EUS outbreak in the Bangweulu swamps but was reported to be commonly affected during a subsequent EUS outbreak in the DRC (Anon 2017). Presumptive lesions of EUS were also commonly observed in E. trimaculatus and C. multispine, two species from which 
the disease has not previously been recorded. As in this study, M. macrolepidotus was shown to be affected during outbreaks of EUS in the Zambezi floodplains, though less commonly than other species, whereas the disease has not previously been recorded from $P$. isidori, a species that occasionally showed small lesions presumptive of EUS. T. sparmanni appeared to be unaffected consistent with the findings of Songe et al., (2012); although Huchzermeyer and Van der Waal (2012) have reported presumptive lesions typical of EUS in this species. It is noteworthy that $P$. philander, an abundant species in the Bangweulu swamps, remained unaffected by the disease.

The optimal functioning of the immune system of fish, as in the case of most poikilothermic animals, is dependent on temperature, but also on other environmental variables. Dramatic environmental change occurs with the onset of the dry season in the Bangweulu swamps. The observed drying of the shallow flood plain, modified by the extensive system of fish weirs, coincided with increasing daily temperature fluctuations associated with cooler autumn nights. Choongo et al. (2009) and Songe et al. (2012) have reported that drops in $\mathrm{pH}$ during the annual flood cycle of the Zambezi floodplains have coincided with outbreaks of EUS in these areas. Seasonal reductions in dissolved oxygen levels, temperature and $\mathrm{pH}$, may compound an increased prevalence of injury associated with migrating out of shallow waters and explain the susceptibility to infection with $A$. invadans of the floodplain fish observed in this study. This is consistent with reports of EUS in the Zambezi floodplain (Choongo et al., 2009; Nsonga et al., 2013; Songe et al., 2012) and in other wetland ecosystems (Pathiratne \& Jayasinghe, 2001).

Together with diatoms, brown algae and golden brown algae, the genus Aphanomyces falls within the kingdom of the Straminopiles. The production of free-swimming spores or zoospores, by which, in the case of $A$. invadans, the disease spreads from one host to the next, is characteristic of these organisms (Walker \& Van West, 2007). The formation of zoospores is one of the most rapid developmental processes in nature, and rapid dispersal of free-swimming zoospores from infected hosts may explain the epidemic spread of disease as observed during this outbreak (Walker \& Van West, 2007). It remains unclear how $A$. invadans survives outside of the host and during periods between outbreaks (Oidtmann, 2012). The ability of zoospores to regain their mobility, after this has been lost in the absence of a suitable surface on which to encyst, may explain spread of the organism with water currents without the need to encyst (Willoughby \& Roberts, 1994) but does not explain the spread of the pathogen between catchments as in the case of the outbreak in the Bangweulu swamps. There is also no clear evidence that fish that have survived an outbreak and demonstrate healed lesions can act as a reservoir of infection (Oidtmann, 2012). Lilley and Roberts (1997) have reported growth of $A$. invadans on agar at $6^{\circ} \mathrm{C}$. Refrigeration and chilling of fish catches are seldom possible in the remote Bangweulu swamp fishery. If not consumed fresh, harvested fish are mostly sun-dried or smoked prior to transport to distant markets. Survival of $A$. invadans in such traded fish products remains unknown.

The annual cycle of drying of the Bangweulu swamps starts in April and results in a migration of fish out of the floodplain back into deeper channels. Affected fish were observed to be amongst the last fish to leave the floodplain and attracted a large 
number and diversity of migratory piscivorous birds. Boys et al. (2012) have speculated on a possible role of such birds in the spread of EUS. A similar mechanism may explain the widely divergent localities from which EUS has been reported in South Africa.

The rich seasonal fish catches from the Bangweulu Wetlands, apart from supporting a large local artisanal fishery, also attract fishermen and fish mongers from other parts of the country (Huchzermeyer, 2013). Mosquito nets are much favoured by artisanal fishermen in Zambia. When sown together, they become bulky and difficult to dry in the wet swamp environment. The survival of spores of $A$. invadans on nets and other fishing gears remains unknown.

Zambia, as a member of the OIE, observes the relevant standards recommended for movement of live fish. The aquatic biosecurity frameworks developed by FAO for Southern Africa (Anon 2009c) have been implemented through regulations governing animal movement which have been enshrined in the Zambian laws under the Fisheries Act 22 of 2011. Despite these regulations, a lack of manpower and resources has affected implementation of the Act and illegal movements of fish are commonplace. Fish imports from Asia, especially of frozen Oreochromis niloticus (Linnaeus) but also some ornamental fish, are common, and border entry points may not be strict enough to check on all imports. Zambia has experienced a rapid expansion in aquaculture, initially based on the culture of non-native $O$. niloticus, a species believed to be resistant to infection with $A$. invadans (Anon 2016a), but now also with native Oreochromis species in catchments not yet invaded by $O$. niloticus. This has resulted in extensive movement of live fish from potentially EUS- infected waters to areas previously free from EUS. The role of infective spores, carried in the transport water associated with shipments of potentially EUS-resistant fish species, remains unknown but provides a plausible pathway for dispersal of the pathogen. As neighbouring countries are facing a similar expansion in aquaculture, the increased movement of live fish within and between these countries provides a rapid means by which $A$. invadans may potentially spread within the region. The Congo River Basin consists of a vast and interconnected aquatic system where anthropogenic and natural fish movements are likely to further the spread of the disease.

\section{Conclusion}

The Bangweulu swamps have been inhabited by fishing communities who have depended on fish in this rich and diverse aquatic ecosystem for many centuries (Brelsford, 1946). Spread of the disease into the Congo River catchment is of grave concern due to the potential impact on the diverse and poorly studied fish fauna within the sensitive rainforest ecosystems on which a large part of the Congolese population depends for its protein.

It is not known how $A$. invadans was introduced onto the African continent. The means by which $A$. invadans has spread between localities and watersheds in Africa remains poorly understood. Potential pathways by which the pathogen may spread need to be better examined, including the roles played by movement of live infected fish, transport water associated with movements of live EUS-resistant fish, water birds, fish products and fishing gears. The rapid spread of EUS in Zambia over the past decade has been paralleled by a rapid development of farming of non-native $O$. niloticus. This has resulted in the extensive movement of fish across the country and plausible means of dispersal of $A$. invadans. 
Despite general measures aimed at limiting the spread of trans-boundary aquatic animal diseases, countries in the affected regions of Africa have difficulty implementing effective control measures. This study adds urgency for further work that might elucidate the means by which EUS has spread through Southern to Central Africa, thereby enabling more effective control measures to be put in place.

\section{Acknowledgements}

The study received no funding and was conducted in the course of the authors' normal work. Sterkspruit Veterinary Clinic in Lydenburg, South Africa, is acknowledged for financial and logistical support. Appreciation is extended to the Directorate Aquaculture Research and Development, Department of Forestry and Fisheries in Cape Town, South Africa, for processing of tissue samples for PCR and to Ampath Pathologists in Nelspruit, South Africa, for preparation of histological sections. African Parks, Bangweulu Wetlands and the local fishing communities are thanked for making access to the park and collection of sick fish possible. Mr N.H. Huchzermeyer from the Department of Geography, Rhodes University in Grahamstown, South Africa, is gratefully acknowledged for preparing the map of the study area. 


\section{References}

Altschul, S. F., Gish, W., Miller, W., Myers, E. W., \& Lipman, D. J. (1990). Basic local alignment search tool. Journal of Molecular Biology, 215, 403-410.

Andrew, T., Huchzermeyer, K., Mbeha, B., \& Nengu, S. (2008). Epizootic ulcerative syndrome affecting fish in the Zambezi river system in Southern Africa. The Veterinary Record, $163,629-632$.

Anon. (2009a). FAO Report of the international emergency disease investigation task force on a serious finfish disease in Southern Africa. 18-26 May 2007. Food and Agriculture Organization of the United Nations, Rome. Viewed December 2016 from http://www.fao.org/d ocrep/o12/io778e/io778eoo.htm

Anon. (2009b). What you need to know about epizootic ulcerative syndrome (EUS) An extension brochure. Rome, Italy: Food and Agriculture Organization of the United Nations, $33 \mathrm{pp}$.

Anon. (2009c). FAO Report of the FAO Workshop on the Development of an Aquatic Biosecurity Framework for Southern Africa. Lilongwe, Malawi, 22-24 April 2008. FAO Fisheries and Aquaculture Report. No. 906. Food and Agriculture Organization of the United Nations, Rome. 55 p.

Anon. (2011). World animal health information database interface: Exceptional epidemiological events, World Organisation for Animal Health, Paris, viewed in 2011, from http://web.oie.int/wahis/public.php?page=country_reports

Anon. (2016a). OIE manual of diagnostic tests for aquatic animals (2016). Paris: World Organization for Animal Health. Viewed January 2017 from http://www.oie.int/international-standard-setting/aquatic-manual/access-online/

Anon. (2016b). African Parks. Annual Report 2015: Conservation at Scale. Johannesburg, South Africa. Viewed December 2016 from https://www.african-parks.org/aboutus/financials-and-annual-reports

Anon. (2017). FAO Report of the international emergency fish disease investigation mission on a suspected outbreak of epizootic ulcerative syndrome (EUS) in the Democratic Republic of the Congo, 13-19 March 2015. Food and Agriculture Organization of the United Nations, Rome. Viewed February 2017 from http://www.fao.org/3/ ai6596e.pdf

Baldock, F. C., Blazer, V. S., Callinan, R. B., Hatai, K., Karunasagar, I., Mohan, C. V., \& Bondad-Reantaso, M. G. (2005) Outcomes of a short expert consultation on epizootic ulcerative syndrome (EUS): Re-examination of causal factors, case definition and nomenclature. In P. Walker, R. J. G. Lester \& M. G. Bondad-Reantaso (Eds.), Diseases in Asian aquaculture V. (pp. 555-585). Manila: Fish Health Section, Asian Fisheries Society.

Blazer, V. S., Lilley, J. H., Schill, W. B., Kiryu, Y., Densmore, C. L., Panyawachira, V., \& Chinabut, S. (2002). Aphanomyces invadans in Atlantic Menhaden along the East Coast of the United States. Journal of Aquatic Animal Health, 14, 1-10.

Boys, C. A., Rowland, S. J., Gabor, M., Gabor, L., Marsh, I. B., Hum, S., \& Callinan, R. B. (2012). Emergence of epizootic ulcerative syndrome in native fish of the Murray-Darling River System, Australia: Hosts, distribution and possible vectors. PLoS One, 7(4), e35568. https://doi. org/10.1371/journal.pone.0035568.

Brelsford, W. V. (1946). Fishermen of the Bangweulu swamps: A study of the fishing activities of the Unga tribe. The Rhodes-Livingstone Papers: Number 12. Manchester: Manchester University Press. 
Callinan, R. B., Paclibare, J. O., Bondad-Reantaso, M. G., Chin, J. C., \& Gogolewski, R. P. (1995). Aphanomyces species associated with epi-zootic ulcerative syndrome (EUS) in the Philippines and red spot disease (RSD) in Australia: Preliminary comparative studies. Diseases of Aquatic Organisms, 21, 233-238.

Choongo, K., Hang'ombe, B., Samui, K. L., Syachaba, M., Phiri, H., Maguswi, C., ... Mataa, L. (2009). Environmental and climatic factors associated with epizootic ulcerative syndrome (EUS) in fish from the Zambezi floodplains, Zambia. Bulletin of Environmental Contamination and Toxicology, 83, 474-478. https://doi.org/dx.doi.org/10.1007/s00128-009-9799-o

Das, M. K., \& Das, R. K. (1993). A review of the fish disease epizootic ulcerative syndrome in India. Environmental Sciences, 11, 134-135.

Egusa, S., \& Masuda, N. (1971). A new fungal disease of Plecoglossus altivelis. Fish Pathology, 6, 41-46.

Huchzermeyer, C. F. (2013). Fish and Fisheries of Bangweulu Wetlands, Zambia. MSc. thesis, Rhodes University, Grahamstown, South Africa. http://hdl.handle.net/10962/d1003927

Huchzermeyer, K. D. A., \& Van der Waal, B. C. W. (2012). Epizootic ulcerative syndrome: Exotic fish disease threatens Africa's aquatic ecosystems. Journal of the South African Veterinary Association, 83, 1-6.

Kolding, J., Ticheler, H., \& Chanda, B. (2003). The Bangweulu swamps - A balanced smallscale multispecies fishery. In E. Jul-Larsen, J. Kolding, J. R. Nielsen, R. Overc \& P. A. M. van Zwieten (Eds.), Management, co-management or no management? Major dilemmas in southern African freshwater fisheries. 2. Case studies (pp. 34-66), FAO Fisheries Technical Paper 426(2). Rome: Food and Agriculture Organization of the United Nations.

Lilley, J. H., \& Roberts, R. J. (1997). Pathogenicity and culture studies comparing the Aphanomyces involved in epizootic ulcerative syndrome (EUS) with other similar fungi. Journal of Fish Diseases, 20, 135-144.

Lilley, J. H., Hart, D., Richards, R. H., Roberts, R. J., Cerenius, L., \& S£der€all,

K. (1997). Pan-Asian spread of single fungal clone results in large scale fish kills. Veterinary Record, 140, 653-654.

McHugh, K. J., Christison, K. W., Weyl, O. L. F., \& Smit, N. J. (2014). Histological confirmation of epizootic ulcerative syndrome in two cyprinid species from Lake Liambezi, Zambezi Region, Namibia. African Zoology, 49(2), 311-316.

McKey, D. B., Durécua, M., Pouilly, M., Béarez, P., Ovando, A., Kalebe,

M., \& Huchzermeyer, C. F. (2016). Present-day African analogue of a pre-European Amazonian floodplain fishery shows convergence in cultural niche construction. Proceedings of the National Academy of Science Early Edition, 1-6. www.doi:10.1073/pnas.1613169114

Musumali, M. M., Heck, S., Husken, S. M. C., \& Wishart, M. (2009). Fisheries in Zambia: An undervalued contributor to poverty reduction. The World-Fish Center policy brief; no. 1913. Washington, DC: World Bank. http://documents.worldbank.org/curated/en/183191468170684519/Fisheries-in-Zambia-anundervalued-contributor-to-poverty-reduction

Nsonga, A., Mfitilodze, W., Samui, K. L., \& Sikawa, D. (2013). Epidemiology of epizootic ulcerative syndrome in the Zambezi River system. A case study for Zambia. Human \& Veterinary Medicine,5(1), 1-8. 
Oidtmann, B. (2012). Review of biological factors relevant to import risk assessments for epizootic ulcerative syndrome (Aphanomyces invadans). Transboundary and Emerging Diseases, 59, 26-39.

Pathiratne, A., \& Jayasinghe, R. P. P. K. (2001). Environmental influence on the occurrence of epizootic ulcerative syndrome (EUS) in freshwater fish in the Bellanwila-Attidiya wetlands, Sri Lanka. Journal of Applied Ichthyology, 17, 30-34.

Phadee, P., Kurata, O., \& Hatai, K. (2004). Detection and identification of fish-pathogenic Aphanomyces piscicida using Polymerase Chain Reaction (PCR) with speciesspecific primers. Journal of Aquatic Animal Health, 16, 25-31.

Pradhan, P., Rathore, G., Sood, N., Swaminathan, T., Yadav, M., Verma, D., .. . Jena, J. (2014). Emergence of epizootic ulcerative syndrome: Large-scale mortalities of cultured and wild fish species in Uttar Pradesh, India. Current Science, 106, 1711-1718.

Sambrook, J., MacCallum, P., \& Russel, D. (2000). Molecular cloning: A laboratory manual, 3rd ed. Long Island, New York, USA: Cold Spring Harbor Laboratory Press.

Scott, L. (2005). Bangweulu-Mweru. In M. L. Thieme, R. Abell, M. L. J. Stiassny, P. Skelton, B. Lehner, G. Teugels, E. Dinerstein, A. Kamdem-Toham, N. Burgess \& D. Olson (Eds.), Freshwater ecoregions of Africa and Madagascar: A conservation assessment (pp. 185-186). Washington: World Wildlife Fund, Island Press.

Songe, M. M., Hang'ombe, M. B., Phiri, H., Mwase, M., Choongo, K., Van der Waal, B., ... Subasinghe, R. P. (2012). Field observations of fish species susceptible to epizootic ulcerative syndrome in the Zambezi River basin in Sesheke District of Zambia. Tropical Animal Health and Production, 44, 179-183. https://doi.org/10.1007/s11250-011-9906-1.

Sosa, E. R., Landsberg, J. H., Stephenson, C. M., Forstchen, A. B., Vandersea, M. W., \& Litaker, R. W. (2007). Aphanomyces invadans and ulcerative mycosis in estuarine and freshwater fish in Florida. Journal of Aquatic Animal Health, 19, 14-26. https://doi.org/10.1577/Ho6-012.1.

Van Steenberge, M., Vreven, E., \& Snoeks, J. (2014). The fishes of the Upper Luapula area (Congo basin): A fauna of mixed origin. Ichthyological Exploration of Freshwaters, 24(4), 329-345.

Walker, C. A., \& Van West, P. (2007). Zoospore development in oomycetes. Review. British Mycological Society. Fungal Biology Reviews, 21, 10-18. Willoughby, L. G., \& Roberts, R. J. (1994). Loss and recovery of zoospore motility in an isolate of Aphanomyces from a diseased fish. Mycological Research, 98, 1463-1464. 